\title{
Digestible Protein Requirement of Pirarucu Juveniles (Arapaima gigas) Reared in Outdoor Aquaculture
}

\author{
F. O. Magalhães Júnior ${ }^{1}$, M. J. M. Santos ${ }^{1}$, I. B. Allaman ${ }^{1}$, I. J. Soares Junior ${ }^{1}$, R. F. Silva ${ }^{2}$ \& L. G. T. Braga ${ }^{1}$ \\ ${ }^{1}$ Laboratory of Nutrition and Fish Feeding (AQUANUT), State University of Santa Cruz (UESC), Ilhéus, Bahia, \\ Brazil \\ ${ }^{2}$ Laboratory of Fish Nutrition and Feeding Behaviour (AquaUFRB), University of Bahia (UFRB), Cruz das Almas, \\ Bahia, Brazil \\ Correspondence: L. G. T. Braga, Laboratory of Nutrition and Fish Feeding (AQUANUT), State University of \\ Santa Cruz (UESC) Ilhéus, Bahia 45662-900, Brazil. Tel: 55-73-99185-0412. E-mail: lgtbraga@gmail.com
}

Received: April 27, $2017 \quad$ Accepted: July 6, $2017 \quad$ Online Published: August 15, 2017

doi:10.5539/jas.v9n9p114 URL: https://doi.org/10.5539/jas.v9n9p114

The research is financed by CAPES and FAPESB.

\begin{abstract}
Pirarucu (Arapaima gigas) is a fast-growing, carnivorous species reared commercially in Amazonian countries as Brazil. Lack of a nutritionally balanced and affordable diet is a major constraint in pirarucu aquaculture, and our investigation sought to estimate the dietary protein requirement for this species. Four diets were formulated to contain increasing concentrations of digestible protein $(32,35,38$, and $41 \%)$ and fed to triplicate groups of juvenile pirarucu of around $2 \mathrm{~kg}$ for 18 weeks. As result, pirarucu showed no differences in feed intake, survival, or fillet yield. However, regression analysis revealed that weight gain (WG) values showed a general increasing trend with increasing dietary digestible protein (DP) level up to $36.7 \%$. In addition, feed conversion rates were also improved with increase in dietary DP up to $36.4 \%$. Fish fed diets containing 32 and $41 \%$ had poor feed conversion rates. Thel protein retention rate (PRR) and protein efficiency index (PER) decreased as levels of DP increased. The optimal dietary protein content for juvenile pirarucu between 1.98 and $4 \mathrm{~kg}$ of BW is about $36 \%$ of digestible protein on diet.
\end{abstract}

Keywords: dietary formulation, feed efficiency, nutritional fish, optimal growth

\section{Introduction}

The pirarucu (Arapaima gigas) is considered to be among the largest freshwater fish in the world, reaching up to $3 \mathrm{~m}$ in length and $200 \mathrm{~kg}$ in body weight (BW) (Pereira-Filho \& Roubach, 2005; Castello, 2008). Wild pirarucu are piscivorous, but can be conditioned to accept extruded feed in aquaculture conditions (Crescêncio et al., 2005; Imbiriba, 2001). As they can grow up to $10 \mathrm{~kg}$ in body weight (BW) in the first year of cultivation, and can be reared at high stocking densities (Cavero, Roubach, Itassú, Gandra, \& Crescêncio, 2003; Brandão, Gomes, \& Chagas, 2006), it has potential to become an economically valuable aquaculture species. In order for this to be fully realized, it is necessary to develop an optimized cultivation diet based on low-cost, nutritionally balanced formulations, in addition to research for reproduction control and low cost of fingerlings (Gatlin, 1995).

Few studies have been conducted concerning the nutritional requirements of this species. Those which have done so mostly observed only young fish of small size-for example, those of approximately $50-120 \mathrm{~g}$ body weight — over a relatively short time period (Santos, Pereira Filho, Sobreira, Ituassú, \& Fonseca, 2010; Ituassú et al., 2005). Since pirarucu is difficult to work with experimentally due to its large size and relative cost, there are few laboratories with appropriate facilities dedicated to the study of larger fish. As nutritional requirements may vary with size, dietary protein source, and environmental conditions, previous results should be complemented with information regarding larger sized fish nutrition.

Protein is one of the main feed components in aquaculture and also one of the most expensive, largely determining the price of feed (Yang et al., 2016). Protein demand is the first nutritional parameter to be estimated for new species in production because it provides the basis for the formulation of practical rations, particularly when there is no additional nutritional information available (NRC, 2011; Kim \& Lee, 2009). When dietary 
protein is provided in excess of its requirement, only a portion is used to synthesize new proteins, while most of the excess amino acids are catabolized and converted into energy (Wilson, 2002). Hence, it is important to optimize protein provision at all phases of growth, in order to keep costs as low as possible (Kumar et al., 2010; Cornelio et al., 2014). The use of digestible protein (DP) in studies of protein requirement allows for efficient aquafeed formulation (Gonçalves \& Carneiro, 2003), resulting in improved utilization of nutrients, increased productivity and profitability of the product.

The farming of pirarucu is under development in Brazil, and the practical diet formulation is currently based on existing diets of other fish species. In the present study, conducted an experiment to determine the protein requirement for juvenile pirarucu, by measuring growth performance, feed efficiency, and body composition.

\section{Materials and Methods}

\subsection{Experimental Design}

A total of 624 juveniles pirarucu were obtained from a commercial hatchery (Aguavale Piscicultura, Ituberá, Bahia, Brazil) and maintained at Experimental Farm of Almada, in Ilhéus, Bahia (18 $43^{\prime} 51^{\prime \prime} \mathrm{S}$ latitude, $44^{\circ} 53^{\prime} 33^{\prime \prime} \mathrm{W}$ longitude). Prior to experimentation, juveniles were kept in holding tanks for 21 days to acclimate to experimental conditions. During this time, they were fed a commercial diet (36\% crude protein). After the period of acclimation had elapsed, the juveniles (initial body weight $1.98 \pm 0.50 \mathrm{~kg}$ ) were placed randomly into 12 tanks $\left(400 \mathrm{~m}^{2}\right.$ each), 156 fish per treatment, at a stocking density of 1 fish per $7.7 \mathrm{~m}^{2}$. This yielded three replicates of each of the four different levels of dietary protein provision. The experiment was conducted outdoors, with photoperiod determined by natural lighting, simulating a practical production system. Fish were hand-fed with experimental diets three times per day, at 8:00 AM, 1:00 PM, and 5:00 PM, for 126 days. During the experimental period, water temperature was $26.6 \pm 1.2{ }^{\circ} \mathrm{C}$ and $\mathrm{pH}$ was $5.84 \pm 0.8$ (YSI Professional Plus multiparameter digital, Yellow Springs, USA).

\subsection{Experimental Diets}

Four diets were formulated to contain increasing levels of protein, ranging from $32,35,38$, and $41 \%$ digestible protein (DP), approximately 36, 39, 42, 44\% crude protein (CP) (Tables 1 and 2). Each diet was designed to be isoenergetic and isolipidic, based on the digestibility studies developed in our laboratory (Cipriano et al., 2015, 2016). Ingredients of the diets were mixed and extruded mechanically with a $6 \mathrm{~mm}$ diameter die (Ferraz Máquinas e Engenharia LTDA, São Paulo, Brazil). Pellets were dried in an oven at $60{ }^{\circ} \mathrm{C}$ for $48 \mathrm{~h}$. Dried feed was stored in plastic bags and refrigerated at $5{ }^{\circ} \mathrm{C}$ until use. 
Table 1. Formulation and composition of four diets (\% natural matter) for juvenile Arapaima gigas

\begin{tabular}{|c|c|c|c|c|}
\hline \multirow{2}{*}{ Ingredient } & \multicolumn{4}{|c|}{ Digestible protein content $(\%)$} \\
\hline & 32 & 35 & 38 & 41 \\
\hline Soybean meal $(45 \%)^{1}$ & 19.00 & 27.40 & 32.70 & 34.00 \\
\hline Corn gluten meal $(60 \%)^{1}$ & 16.00 & 15.00 & 13.85 & 21.00 \\
\hline Fish meal $(55 \%)^{1}$ & 14.00 & 14.50 & 15.00 & 14.00 \\
\hline Meat and bones meal $(45 \%)^{1}$ & 7.10 & 7.10 & - & - \\
\hline Poultry offal meal ${ }^{1}$ & 5.80 & 7.10 & 15.10 & 16.50 \\
\hline Corn meal $^{1}$ & 7.00 & 7.30 & 7.65 & 7.60 \\
\hline Wheat bran ${ }^{1}$ & 25.50 & 16.20 & 11.10 & 3.00 \\
\hline Soybean oil $^{1}$ & 4.71 & 4.51 & 3.71 & 3.01 \\
\hline Salt & 0.28 & 0.28 & 0.28 & 0.28 \\
\hline Mineral and vitamin premix* & 0.50 & 0.50 & 0.50 & 0.50 \\
\hline Antifungal & 0.08 & 0.08 & 0.08 & 0.08 \\
\hline Antioxidant $(\mathrm{BHT})^{2}$ & 0.01 & 0.01 & 0.01 & 0.01 \\
\hline Vit. C mon $35^{1}$ & 0.02 & 0.02 & 0.02 & 0.02 \\
\hline \multicolumn{5}{|l|}{ Real proximate composition } \\
\hline Moisture (\%) & 10.22 & 10.43 & 9.95 & 9.82 \\
\hline Crude protein $(\%)$ & 35.72 & 39.25 & 42.08 & 44.31 \\
\hline Digestible protein*(\%) & 32.00 & 35.00 & 38.00 & 41.00 \\
\hline Gross energy $\left(\mathrm{MJ} \mathrm{kg}^{-1}\right)$ & 20.45 & 19.26 & 19.02 & 19.29 \\
\hline Digestible energy $\left(\mathrm{MJ} \mathrm{kg}^{-1}\right)^{*}$ & 13.28 & 13.02 & 13.38 & 13.43 \\
\hline Ether extract $(\%)$ & 9.13 & 8.90 & 8.14 & 8.55 \\
\hline Acid detergent fibre (\%) & 18.64 & 24.58 & 17.65 & 15.39 \\
\hline Neutral detergent fibre $(\%)$ & 34.08 & 37.57 & 34.07 & 30.19 \\
\hline
\end{tabular}

Note. *Protein and digestible energy based on the percentage of digestibility of ingredient for pirarucu juvenile (Arapaima gigas) of Cipriano et al. (2015, 2016).

${ }^{1}$ Pratigi Alimentos, Castro Alves, BA, BR.

Composition $/ \mathrm{kg}$ of the product: vit. $\mathrm{A}=6,000.000 \mathrm{IU}$; vit. $\mathrm{D} 3=2,250.000 \mathrm{IU}$; vit. $\mathrm{E}=75.000 \mathrm{mg}$; vit. $\mathrm{K} 3=$ $3.000 \mathrm{mg}$; vit thiamine $=5.000 \mathrm{mg}$; riboflavin $=10.000 \mathrm{mg}$; vit. pyridoxine $=8.000 \mathrm{mg}$; Biotin $=2000 \mathrm{mg}$; vit. $\mathrm{C}=192.500 \mathrm{mg}$; Niacin $=30.000 \mathrm{mg}$; Folic acid $=3.000 \mathrm{mg} ; \mathrm{Fe}=100.000 \mathrm{mg} ; \mathrm{Cu}=600 \mathrm{mg} ; \mathrm{Mn}=60.000 \mathrm{mg}$; $\mathrm{Zn}=150.000 \mathrm{mg} ; \mathrm{I}=4.500 \mathrm{mg} ; \mathrm{Cu}=15.000 \mathrm{mg} ; \mathrm{Co}=2000 \mathrm{mg} ; \mathrm{If}=400 \mathrm{mg}$;

${ }^{2} \mathrm{BHT}=$ Butylated hydroxytoluene. 
Table 2. Amino acid analysis of diets (dry matter)

\begin{tabular}{|c|c|c|c|c|c|}
\hline \multirow{2}{*}{ Amino acids } & & \multicolumn{4}{|c|}{ Digestible protein content $(\%)$} \\
\hline & & 32 & 35 & 38 & 41 \\
\hline \multirow[t]{9}{*}{ Essentials } & Isoleucin & 9.35 & 8.70 & 8.95 & 9.50 \\
\hline & Leucin & 5.55 & 5.50 & 4.85 & 5.20 \\
\hline & Lysine & 5.90 & 5.55 & 5.6 & 5.25 \\
\hline & Metionin & 2.10 & 1.90 & 1.80 & 2.30 \\
\hline & Phenylalanine & 6.75 & 6.25 & 6.55 & 7.60 \\
\hline & Treonin & 4.75 & 4,00 & 3.90 & 3.95 \\
\hline & Valine & 4.80 & 5.65 & 5.55 & 5.20 \\
\hline & Arginine & 7.20 & 7.40 & 7.20 & 6.95 \\
\hline & Histidine & 2.75 & 2.60 & 2.65 & 2.55 \\
\hline \multirow[t]{9}{*}{ Non - Essentials } & Alanine & 5.30 & 4.85 & 5.05 & 5.05 \\
\hline & Aspartate & 8.15 & 9.10 & 8.85 & 9,00 \\
\hline & Cisteín & 1.30 & 2.70 & 2.70 & 2.55 \\
\hline & Glutamine & 18.5 & 19.1 & 18.15 & 18.5 \\
\hline & Glycine & 3.25 & 4.40 & 4.55 & 4.35 \\
\hline & Proline & 7.00 & 6.55 & 7.05 & 6.75 \\
\hline & Serine & 5.90 & 5.85 & 6.25 & 5.90 \\
\hline & Tyrosine & 5.05 & 4.35 & 4.20 & 3.95 \\
\hline & Taurine & 0.25 & 0.45 & 0.45 & 0.50 \\
\hline
\end{tabular}

\subsection{Sample Collection}

At the end of the trial period, all fish were sacrificed using a pneumatic captive bolt gun (TEC 10 PP; Cachoeirinha, Brazil). Two individuals per tank were sampled for fillet analysis, which was conducted at the Fish Processing Unit and Health Inspection Service of the Bahia state government by members of staff, without the intervention of the researchers.

\subsection{Growth Parameters}

At the end of the trial, following variables per tank were evaluated:

Weight gain $(\mathrm{BW})=$ final $\mathrm{BW}(\mathrm{kg})-$ initial BW $(\mathrm{kg})$.

Feed intake $(\mathrm{FI})=\sum[($ daily feed intake per tank $(\mathrm{g})) /($ number of fish $)]$

Feed conversion rate $(\mathrm{FCR})=$ live weight gain $(\mathrm{g}) /$ dry feed intake $(\mathrm{g})$.

Survival $=100 \times($ final number of fish/initial number of fish $)$.

Fillet yield (FY): FY $=100 \times($ final BW/fillet weight).

Protein retention rate $(\mathrm{PRR})=100 \times($ final $\mathrm{BW} \times$ final body protein mass $)-($ initial $\mathrm{BW} \times$ initial body protein mass)/protein intake.

Protein efficiency ratio $(\mathrm{PER})=$ weight gain/protein intake

\subsection{Chemical Analysis}

The composition of experimental diets and fillets were analyzed according to AOAC (2005). Diet moisture was determined by drying the samples for $24 \mathrm{~h}$ at $105{ }^{\circ} \mathrm{C}$. Crude protein content was estimated using the micro-Kjeldahl method $(\mathrm{N} \times 6.25)$. Crude fat content was estimated using diethyl ether extraction, ash by heating at $550^{\circ} \mathrm{C}$ for $24 \mathrm{~h}$ and nitrogen free extract (NFE) as the remainder. The gross energy of diets and fillets were calculated using bomb calorimetry (IKA Instrument Co., Staufen, BKG, DE).

\subsection{Statistical Analysis}

The association between the protein levels of the experimental diets with weight gain and feed conversion rate was established using regression analyses to estimate the optimal DP level of the diets for pirarucu juveniles. The statistical program R Development Core Team (2008) was used for all statistical analyses. 


\section{Results}

Since pirarucu have bimodal respiration (Lefevre et al., 2016), dissolved oxygen is not a key requirement for cultivation; however, this parameter was routinely measured $\left(3.29 \pm 1.6 \mathrm{mg} \mathrm{L}^{-1}\right)$. All parameters evaluated were within tolerance ranges according to Del Risco et al. (2008). No mortalities occurred during the experiment. Feed intake $(p=0.0897)$, fillet yield $(p=0.6187)$ and final weight $(p=0.6104)$ were not affected by dietary protein levels (Table 3$)$. However, weight gain $(W G)(p=0.0237)$, feed conversion rate $(p=0.0012)$, protein retention rate $(p=0.0025)$ and protein efficiency ratio $(p=0.001)$ did differ significantly (Table 3$)$.

Table 3. Growth parameters of pirarucu juveniles fed with experimental diets

\begin{tabular}{llllll}
\hline & \multicolumn{5}{c}{ Digestible protein content (\%) } \\
\cline { 2 - 5 } & 32 & 35 & 38 & 41 & P-value \\
\hline Initial weight (kg) & $2.00 \pm 0.08$ & $2.01 \pm 0.09$ & $1.90 \pm 0.10$ & $2.01 \pm 0.06$ & - \\
Final weight (kg) & $3.96 \pm 0.38$ & $4.28 \pm 0.27$ & $4.27 \pm 0.42$ & $4.02 \pm 0.36$ & 0.6104 \\
Weight gain(kg) & $1.96 \pm 0.06$ & $2.27 \pm 0.11$ & $2.37 \pm 0.14$ & $2.01 \pm 0.08$ & 0.0237 \\
Feed intake (kg) & $4.78 \pm 0.71$ & $4.52 \pm 0,80$ & $5.30 \pm 0.57$ & $5.55 \pm 0.73$ & 0.0897 \\
Feed conversion rate ${ }^{*}$ & $2.48 \pm 0.18$ & $2.03 \pm 0.03$ & $2.24 \pm 0.22$ & $2.46 \pm 0.12$ & 0.0012 \\
Protein retention rate $^{*}$ & $24.88 \pm 0.41$ & $23.41 \pm 0.29$ & $20.33 \pm 0.28$ & $18.12 \pm 0.36$ & 0.0025 \\
Protein efficiency ratio $^{*}$ & $1.20 \pm 0.01$ & $1.22 \pm 0.02$ & $1.00 \pm 0.06$ & $0.97 \pm 0.12$ & 0.0001 \\
Fillet yield (\%) $^{*}$ & $37.72 \pm 0.45$ & $37.57 \pm 0.23$ & $38.13 \pm 0.34$ & $38.46 \pm 0.40$ & 0.6187 \\
\hline
\end{tabular}

Note. ${ }^{*}$ Weight gain $\left(\mathrm{y}=-0.0187 \mathrm{x}^{2}+1.3613 \mathrm{x}-22.87\right)$; Feed conversion rate $\left(\mathrm{y}=0.0310 \mathrm{x}^{2}-2.2344 \mathrm{x}+42.44\right)$; Protein retention rate $(y=-0.030 x+2.197)$; Protein efficiency ratio $(y=-0.778 x+50.09)$.

Weight gain increased up to the optimum level of $36.4 \%$ of digestible protein in the diet, then decreased with increasing protein level in the diet (Figure 1). Feed conversion rate (FCR) also improved with increasing DP level (Figure 2).

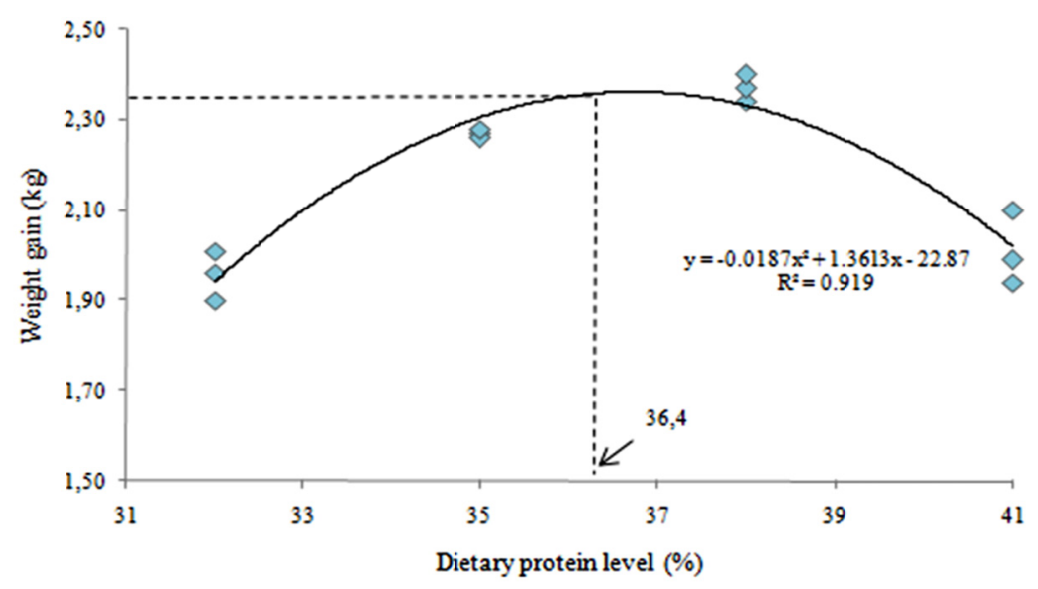

Figure 1. Polynomial regression of weight gain for pirarucu juveniles fed with experimental diets 




Figure 2. Polynomial regression of the feed conversion ratio and digestible protein levels for pirarucu juveniles fed with experimental diets.

Quadratic analysis showed that the optimum feed conversion rate was 2.13 , achieved with $36 \%$ of digestible protein in the diet. In analyzed fillets, no significant differences were observed across the diets in ash content, moisture, protein, ether extract, or gross energy (Table 4).

Table 4. Proximate composition of pirarucu filets fed with experimental diets (based on natural matter)

\begin{tabular}{llllll}
\hline \multirow{2}{*}{ Variable } & \multicolumn{5}{c}{ Digestible protein content (\%) } \\
\cline { 2 - 6 } & 32 & 35 & 38 & 41 & P-value \\
\hline Ashes (\%) & $0.98 \pm 0.09$ & $0.87 \pm 0.10$ & $0.97 \pm 0.08$ & $0.96 \pm 0.11$ & 0.3969 \\
Humidity (\%) & $76.61 \pm 0.68$ & $77.92 \pm 0.58$ & $76.38 \pm 0.66$ & $77.54 \pm 0.61$ & 0.7348 \\
Crude protein (\%) & $20.0 \pm 0.71$ & $18.75 \pm 0.62$ & $20.16 \pm 1.10$ & $19.16 \pm 0.66$ & 0.8792 \\
Ether extract (\%) & $3.67 \pm 0.33$ & $3.31 \pm 0.24$ & $3.68 \pm 0.31$ & $3.49 \pm 0.17$ & 0.8421 \\
Gross energy (MJ/kg) & $5.31 \pm 0.24$ & $5.13 \pm 0.21$ & $5.44 \pm 0.17$ & $5.13 \pm 0.19$ & 0.6202 \\
\hline
\end{tabular}

\section{Discussion}

Although final weight and survival were not different across treatments, some performance data of juvenile pirarucu showed a favorable trend with increasing dietary protein level up to a point, followed by subsequent decrease. We observed a positive relationship between feed conversion rate (FCR) and a diet with $\sim 36 \%$ of DP. Similarly, fish weight gain further improved under a diet with 35 to $38 \%$ of DP. These results are different to studies with juvenile pirarucu $(\sim 120 \mathrm{~g})$, which showed differences in specific growth rates and weight gain related to the level of protein in the diet, but not in feed conversion rate (Ituassú et al., 2005). However, Del Risco et al. (2008) observed no significant differences in FCR between pirarucu fed at $40 \%$ and $45 \%$ CP, in juveniles of 85-470 g BW. Mattos et al. (2016), studying the regulation of protein intake and diet selection, concluded that pirarucu of $\sim 650 \mathrm{~g} \mathrm{BW}$ preferred a protein intake at $45 \% \mathrm{CP}$. Similar studies performed in other tropical freshwater carnivorous species, showed a protein requirement of $45 \%$ DP for barred sorubim (Pseudoplatystoma reticulatum) of $16 \mathrm{~g} \mathrm{BW}$ and 38\% CP for spotted catfish (Pseudoplatystoma sp.) of $360 \mathrm{~g}$ BW (Cornelio et al., 2014; Honorato et al., 2015). According to Ituassú et al. (2005), the bioavailability of food in different studies may have influenced findings. In our study, more recently available information on digestible dietary ingredients (Cipriano et al., 2015, 2016) guided the choice of ingredients for the diet formulation, which may have improved dietary protein utilization. It is clear that differences in the digestibility of protein and various energy sources used in diet preparation can have significant effects on the estimation of protein requirements. However, we also suggest that the difference in results is due to the difference in size of fish. Some previous protein requirement experiments with pirarucu have been performed using fingerlings (Ituassú et al., 2005; Del Risco et al., 2008), animals with low initial weight and rapid growth responses over a short time, 
whereas the present study utilized much larger individuals. Our study also differs in our use of extruded feed rather than pellet feed, which may have increased the bioavailability of the nutrients.

Varying levels of protein in the diet did not affect feed intake, but did affect feed conversion rate (FCR). Fish fed a diet with $\sim 36 \%$ DP by polynomial regression analysis showed optimum FCR (2.03), suggesting that this protein level is suitable for maximal protein synthesis. The FCR found in the present study was similar to Ituassú et al. (2005), who found an FCR of 2.3 in $120 \mathrm{~g}$ fish. However, those results differed from Del Risco et al. (2008), who found an FCR of 1.07 in fish of $86-470 \mathrm{~g}$ fed CP at $40 \%$. These variable findings could be due to energy use in protein deposition. Additionally, it is known that the energy-to-protein ratio plays an important role in fish nutrition, which can affect growth performance and feed efficiency. According to Yang et al. (2016) and NRC (2011), expressing protein requirement based on the protein-to-energy ratio is more rational than the dietary crude "protein requirement" expression. Using this expression, pirarucu in our study fed a digestible energy/digestible protein ratio (E/P) of $35.8 \mathrm{~kJ} \mathrm{~kg}^{-1}$ showed optimum performance in weight gain and feed conversion rate. This suggests that this ratio was suitable for maximal protein synthesis.

Skinless fillet yield (FY) had no significant differences among treatments. This result is consistent with a study of a carnivorous freshwater specie (Pseudoplatystoma sp.) reared under similar conditions of commercial aquaculture (Honorato et al., 2015). However, higher yields of $47-50 \%$ were recorded by Fogaça, Oliveira, Carvalho, and Santos (2011) evaluating pirarucu juveniles of 7-16 kg BW. In assessing the skinless FY of cultivated pirarucu, Oliveira, Jesus, Batista, and Lessi (2014) reported a mean value of $41 \%$ for fish weighing between $6-9 \mathrm{~kg}$. This variation may be due to the age of the fish.

PER and PRR decreased significantly with increased dietary protein content. As previously discussed, excess dietary protein beyond requirement is directed towards energy production (Yang et al., 2016). The trends in protein use observed in this study are similar to several previously studies for other carnivorous fish (Abbas, Siddiqui, \& Jamil, 2011; K. Kim, Lim, Kang, K. Kim, \& Son, 2012; Mohseni, Pourkazemi, Hosseni, Hassani, \& Bai, 2013; Coutinho et al., 2014). In some cases, fish body protein content tends to increase with increasing protein level in the diet (Zhang, Gong, Y. Yuan, Chu, \& H. Yuan, 2009; Zhang et al., 2010). However, in the current study, the protein content in the pirarucu youth fillet was not significantly affected by the dietary DP levels. These results concurred with those observed in the body protein content of other fish species (Abbas et al., 2011; Guo et al., 2012; Deng et al., 2014). Similarly, ash content, moisture, crude energy, and fillet lipids were not affected by changes in dietary protein levels. This is also consistent with other studies in some fish species (Monentcham, Pouomogne, \& Kestemont, 2010; Akpinar, Sevgili, Ozgen, Demir, \& Emre, 2012). Dry matter and $\mathrm{CP}$ values were similar to those found in pirarucu juvenile fillets of 7-16 kg by Fogaça et al. (2011). These results lead us to propose studies on liver metabolism in pirarucu. Liver plays an important function in maintaining body composition in fish, but there is some variation of information in the literature on fish liver function subjected to dietary protein changes (Kim \& Lee, 2009; Yang et al., 2016).

\section{Conclusion}

The optimal dietary protein requirement for juvenile pirarucu between 1.98 and $4 \mathrm{~kg}$ of BW is estimated to be around $36 \%$ digestible protein. This information will be useful in developing accurately balanced diets for cultivating this species.

\section{Acknowledgements}

This project was supported by Coordination for the Improvement of Higher Education Personnel (CAPES) and Bahia Research Foundation (FAPESB-PNE013/2014), Brazil. The Pratigi Alimentos SA (Bahia, Brazil) provided the rations for this project.

\section{References}

Abbas, G., Siddiqui, P. J. A., \& Jamil, K. (2011). The Optimal Protein Requirements of Juvenile Mangrove Red Snapper, Lutjanus argentimaculatus Fed Isoenergetic Diets. Pakistan Journal of Zoology, 44, 469-480.

Akpinar, Z., Sevgili, H., Ozgen, T., Demir, A., \& Emre, Y. (2012). Dietary protein requirement of juvenile shi drum, Umbrina cirrosa. Aquaculture Research, 43, 421-429. https://doi.org/10.1111/j.1365-2109.2011. 02845. $\mathrm{x}$

Association of Official Analytical Chemists (International) [AOAC]. (2005). Official Methods of Analysis (18th ed.). AOAC Int., Gaithersburg, MD, USA. 
Brandão, F. R., Gomes, L. C., \& Chagas, E. C. (2006). Stress responses of pirarucu (Arapaima gigas) during routine aquaculture practices. Acta Amazonica, 36, 349-356. https://doi.org/10.1590/S0044-596720060003 00010

Castello, L. (2008). Lateral migration of Arapaima gigas in floodplains of the Amazon. Ecology of Freshwater Fish, 17, 38-46. https://doi.org/10.1111/j.1600-0633.2007.00255.x

Cavero, B., Roubach, R., Itassú, D. R. A., Gandra, A. L., \& Crescêncio, R. (2003). Pirarucu (Arapaima gigas) husbandry in ponds. Acta Amazônica, 33, 715-718. https://doi.org/10.1590/S0044-59672003000400017

Cipriano, F. S., Lima, K. S., Passinato, E. B., Jesus, R. M., Magalhães Junior, F. O., Tonini, W. C. T., \& Braga, L. G. T. (2015). Apparent digestibility of energetic ingredients by pirarucu juveniles, Arapaima gigas (Schinz, 1822). Latin American Journal of Aquatic Research, 43, 786-791. https://doi.org/10.3856/ vol43-issue4-fulltext-18

Cipriano, F. S., Lima, K. S., Souza, R. H. B., Tonini, W. C. T., Passinato, E. B., \& Braga, L. G. T. (2016). Digestibility of animal and vegetable protein ingredients by pirarucu juveniles (Arapaima gigas). Revista Brasileira de Zootecnia, 45, 581-586. https://doi.org/10.1590/S1806-92902016001000001

Cornélio, F. H. G., Da Cunha, D. A., Silveira, J., Alexandre, D., Silva, C. P., \& Fracalossi, D. M. (2014). Dietary protein requerimento of juvenile Cachara Catfish, Pseudoplatystoma reticulatum. Journal of the World Aquaculture Society, 45, 45-54. https://doi.org/10.1111/jwas.12090

Coutinho, F., Peres, H., Castro, C., Pérez-Jiménez, A., Magalhães, R., Pousão-Ferreira, P., \& Oliva-Teles, A. (2014). Dietary protein requirement of zebra sea bream (Diplodus cervinus, Lowe 1838) juveniles. Aquaculture Nutrition, 22, 564-471. https://doi.org/10.1111/anu.12269

Crescêncio, R., Itassú, D. R., Roubach, R., Pereira-Filho, M., Cavero, B. A., \& Gandra, A. L. (2005). Influence of feeding period on consumption and weight gain of pirarucu. Pesquisa Agropecuária Brasileira, 40, 1217-1222. https://doi.org/10.1590/S0100-204X2005001200009

Del Risco, M., Velásquez, J., Sandoval, M., Padilla, P., Mori-Pinedo, L., \& Chu-Koo, F. (2008). Efecto de tres niveles de proteína dietaria en el crecimiento de juveniles de paiche, Arapaima gigas (Shinz, 1822). Folia Amazónica, 17, 29-37. https://doi.org/10.24841/fa.v17i1-2.264

Deng, J. M., Xizhang, X., Han, X., Tao, L., Bi, B., \& Kang, B. (2014). Dietary Protein Requirement of Juvenile Dianchi Golden-line Barbell, Sinocyclocheilus grahami. Journal World Aquaculture Society, 45, 421-429. https://doi.org/10.1111/jwas. 12137

Fogaça, F. H. S., Oliveira, E. G., Carvalho, S. E. Q., \& Santos, F. J. S. (2011). Yield and composition of pirarucu fillet in different weight classes. Acta Scientiarum, Animal Sciences, 33, 95-99. https://doi.org/10.4025/ actascianimsci.v33i1.10843

Gatlin, D. M. (1995). Review of red drum nutrition. In C. M. Lim \& D. J. Sessa (Eds.), Nutrition and Utilization Technology in Aquaculture (pp. 41-49). AOCS Press, Champaign, IL, USA.

Gonçalves, E. G., \& Carneiro, D. J. (2003). Apparent digestibility coefficients of protein and energy of some ingredients used in diets for pintado, Pseudoplatystoma corruscans (Agassiz, 1829). Revista Brasileira de Zootecnia, 32, 779-786. https://doi.org/10.1590/S1516-35982003000400001

Guo, Z. Q., Zhu, X., Liu, J., Yang, Y., Lan, Z., \& Xie, S. (2012). Effects of dietary protein level on growth performance, nitrogen and energy budget of juvenile hybrid sturgeon, Acipenser baerii female $\times A$. gueldenstaedtii male. Aquaculture, 338, 89-95. https://doi.org/10.1016/j.aquaculture.2012.01.008

Honorato, C. A., Ushizima, T. T., Santamaria, F. M., Flores-Quintana, C. I., Marcondes, V. M., \& Nascimento, C. A. (2015). Growth performance and economic of Pseudoplatystoma sp fed with protein levels reared in net cages. Arquivo Brasileiro de Medicina Veterinária e Zootecnia, 67, 1408-1414. https://doi.org/10.1590/ $1678-4162-7238$

Imbiriba, E. P. (2001). Produtcion Potential of Pirarucu, Arapaima gigas, in Capyivity. Acta Amazonica, 31, 299-316. https://doi.org/10.1590/1809-43922001312316

Ituassú, D. R., Pereira-Filho, M., Roubach, R., Crescêncio, R., Cavero, B. A., \& Gandra, A. L. (2005). Crude protein levels for juvenile pirarucu. Pesquisa Agropecuária Brasileira, 40, 255-259. https://doi.org/10.1590/ S0100-204X2005000300009 
Kim, K., Lim, S. G., Kang, Y. J., Kim, K., \& Son, M. H. (2012). Effects of Dietary Protein and Lipid Levels on Growth and Body Composition of Juvenile Far Eastern Catfish, Silurus asotus. Asian-Australasian Journal of Animal Sciences, 25, 369-374. https://doi.org/10.5713/ajas.2011.11089

Kim, S. S., \& Lee, K. J. (2009). Dietary protein requirement of juvenile tiger puffer (Takifugu rubripes). Aquaculture, 287, 219-222. https://doi.org/10.1016/j.aquaculture.2008.10.021

Kumar, V., Sahu, N., Pal, A., Kumar, S., Sinha, A., Ranjan, J., \& Baruah, K. (2010). Modulation of key enzymes of glycolysis, gluconeogenesis, amino acid catabolism, and TCA cycle of the tropical freshwater fish Labeo rohita fed gelatinized and non-gelatinized starch diet. Fish Physiology and Biochemistry, 36, 491-499. https://doi.org/10.1007/s10695-009-9319-5

Lefevre, S., Bayley, M., \& McKenzie, D. J. (2016). Measuring oxygen uptake in fishes with bimodal respiration. Journal of Fish Biology, 88, 206-231. https://doi.org/10.1111/jfb.12698

Mattos, B. O., Filho, E. C. T. N., Santos, A. A., Barreto, K. A., Vázquez, F. J. S., \& Silva, R. F. (2016). A new approach to feed frequency studies and protein intake regulation in juvenile pirarucu. Annals of the Brazilian Academy of Sciences, In press. https://doi.org/10.1590/0001-3765201720160349.

Mohseni, M., Pourkazemi, M., Hosseni, M. R., Hassani, M. H. S., \& Bai, S. C. (2013). Effects of the dietary protein levels and the protein to energy ratio in sub-yearling Persian sturgeon, Acipenser persicus (Borodin). Aquaculture Reseach, 44, 378-387. https://doi.org/10.1111/j.1365-2109.2011.03041.x

Monentcham, S. E., Pouomogne, V., \& Kestemont, P. (2010). Influence of dietary protein levels on growth performance and body composition of African bonytongue fingerlings, Heterotis niloticus (Cuvier, 1829). Aquaculture Nutrition, 16, 144-152. https://doi.org/10.1111/j.1365-2095.2008.00646.x

National Research Council (NRC). (2011). Nutrient requirements of fish and shrimp (p. 432). Washington, DC: National Academy Press.

Oliveira, P. R., Jesus, R. S., Batista, G. M., \& Lessi, E. (2014). Sensorial, physicochemical and microbiological assessment of pirarucu (Arapaima gigas, Schinz 1822) during ice storage. Brazilian Journal of Food Technology, 17, 67-74. https://doi.org/10.1590/bjft.2014.010

Pereira-Filho, M., \& Roubach, R. (2005). Criação de Pirarucu. In B. Baldisseroto \& L. C. Gomes (Eds.), Criação de Espécies Nativas de Peixes (pp. 37-66). Santa Maria: UFSM.

R Development Core Team. (2011). R: A language and environment for statistical computing. R. Foundation for Statistical Computing, Vienna, Austria. Retrieved December 1, 2016, from http://www.R-project.org

Saint-Paul, U. (1986). Potencial for aquaculture of South American freshwater fishes: A rewiew. Aquaculture, 54, 205-240. https://doi.org/10.1016/0044-8486(86)90329-7

Santos, L., Pereira Filho, M., Sobreira, C., Ituassú, D. R., \& Fonseca, F. A. L. (2010). Protein requirement of tambaqui juveniles (Colossoma macropomum) after feed deprivation. Acta Amazonica, 40, $597-604$. https://doi.org/10.1590/S0044-59672010000300021

Wilson, R. P. (2002). Amino acids and proteins. In J. E. Halver \& R. W. Hardy (Eds.), Fish Nutrition (3rd ed., pp. 143-179). Academic Press, New York.

Yang, M., Wang, J., Han, T., Yang, Y., Li, X., \& Jiang, Y. (2016). Dietary protein requirement of juvenile bluegill sunfish (Lepomis macrochirus). Aquaculture, 459, 191-197. https://doi.org/10.1016/j.aquaculture.2016. 03.044

Zhang, G., Gong, S., Yuan, Y., Chu, Z., \& Yuan, H. (2009). Dietary protein requirement for juvenile Chinese sucker (Myxocyprinus asiaticus). Journal of Applied Ichthyology, 25, 715-718. https://doi.org/10.1111/ j.1439-0426.2009.01280.x

Zhang, J., Zhou, F., Whang, L., Shao, Q., Xu, Z., \& Xu, J. (2010). Dietary Protein Requirement of Juvenile Black Sea Bream, Sparus macrocephalus. Journal of the World Aquaculture Society, 41, 151-164. https://doi.org/10.1111/j.1749-7345.2010.00356.x

\section{Copyrights}

Copyright for this article is retained by the author(s), with first publication rights granted to the journal.

This is an open-access article distributed under the terms and conditions of the Creative Commons Attribution license (http://creativecommons.org/licenses/by/4.0/). 